\title{
Punctaporonins H-M: Caryophyllene-Type Sesquiterpenoids from the Sponge-Associated Fungus Hansfordia sinuosae
}

\section{Zehong Wu ${ }^{1}$, Dong Liu ${ }^{1}$, Peter Proksch ${ }^{2}$, Peng Guo ${ }^{3, *}$ and Wenhan Lin ${ }^{1, *}$}

1 State Key Laboratory of Natural and Biomimetic Drugs, Peking University, Beijing 100191, China; E-Mails: wuzehong922@126.com (Z.W.); liudong_1982@126.com (D.L.)

2 Institute für Pharmazeutische Biologie und Biotechnologie, Heinrich-Heine-Universität Düsseldorf, Universitätsstr. 1, Geb.26.23, 40225 Düsseldorf, Germany; E-Mail: Proksch@uni-duesseldorf.de

3 Pharmacology and Toxicology Research Center, Institute of Medicinal Plant Development, Chinese Academy of Medical Sciences, Peking Union Medical College, Beijing 100193, China

* Authors to whom correspondence should be addressed; E-Mails: pguo@ implad.ac.cn (P.G.); whlin@bjmu.edu.cn (W.L.); Tel./Fax: +86-10-5783-3235 (P.G.);

Tel./Fax: +86-10-8280-6188 (W.L.).

Received: 11 April 2014; in revised form: 20 May 2014 / Accepted: 5 June 2014 /

Published: 30 June 2014

\begin{abstract}
Six new caryophyllene-based sesquiterpenoids named punctaporonins H-M (1-6), together with punctaporonin B (7) and humulane (8) were isolated from the fermentation broth of the sponge-derived fungus Hansfordia sinuosae. Their structures were determined by the extensive HRESIMS and NMR spectroscopic analysis, including the X-ray crystallographic data for the assignment of the absolute configurations of punctaporonins $\mathrm{H}-\mathrm{I}$ (1-2). The isolated compounds were evaluated for antihyperlipidemic, cytotoxic and antimicrobial activities, and punctaporonin $\mathrm{K}(4)$ exhibited potent effects to reduce the triglycerides and total cholesterol in the intracellular levels.
\end{abstract}

Keywords: sponge-associated fungus; Hansfordia sinuosae; punctaporonins $\mathrm{H}-\mathrm{M}$; structural elucidation; lowering lipid accumulation

\section{Introduction}

Caryophyllene-based sesquiterpenoids are a group of structurally unique natural products characterized by the presence of a bicyclo[2.7.0]undecane skeleton, in addition to the backbone-rearranged 
polycyclic derivatives [1]. The majority of caryophyllene-related analogues have been isolated from terrestrial plants [2-4] and the plant-associated fungal species [5-12]. Marine-derived caryophyllane-type compounds were found from the soft coral Sinularia nanolobata $[13,14]$ and the gorgonian coral Subergorgia suberosa [15], while fuscoatrol A is the only caryophyllene sesquiterpene isolated from the marine fungus Humicola fuscoatra [16]. Some caryophyllene derivatives exhibited immunosuppressive [9], cytotoxic [15], and antibiotic activities [17,18]. As part of our ongoing search for the chemical diversity from marine-derived microorganisms, the sponge (Niphates sp.) associated fungus Hansfordia sinuosae (WGCA-25-3A) was isolated. Chemical examination of the ethyl acetate extract of the solid fermented $H$. sinuosae resulted in the isolation of six new sesquiterpenoids (1-6) together with two known analogues (Figure 1).

Figure 1. Structures of punctaporonins H-M (1-6), punctaporonin B (7) and humulane (8).
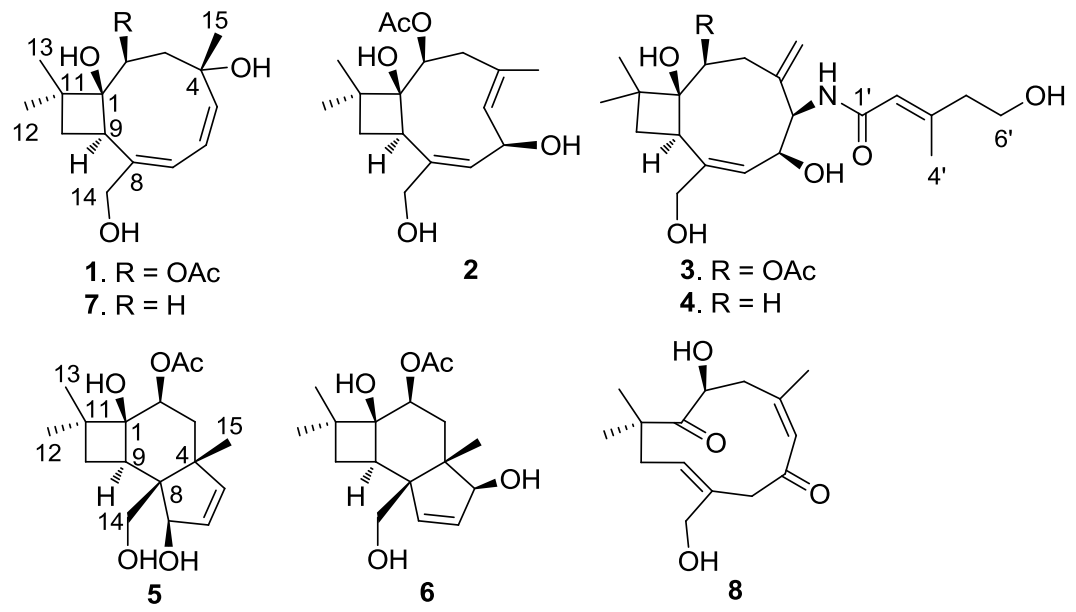

\section{Results and Discussion}

\subsection{Structure Elucidation}

The molecular formula of punctaporonin $\mathrm{H}(\mathbf{1})$ was determined as $\mathrm{C}_{17} \mathrm{H}_{26} \mathrm{O}_{5}$ on the basis of its HRESIMS and NMR data, requiring five degrees of unsaturation. The IR absorptions at 3350 and $1708 \mathrm{~cm}^{-1}$ suggested the presence of hydroxy and carbonyl groups. Inspection of the ${ }^{13} \mathrm{C} \mathrm{NMR}$ and DEPT spectra revealed seventeen carbon resonances characterized by four olefinic carbons for two double bonds and a carbonyl carbon, while the ${ }^{1} \mathrm{H}$ NMR spectrum displayed four methyl singlets, three olefinic protons, three methylene, and an oxymethine. Thus, the remaining degrees of the molecular unsaturation accounted for a bicyclic skeleton. A cyclobutane ring was evident from the COSY correlation between $\mathrm{H}-9\left(\delta_{\mathrm{H}} 3.26\right.$, dd, $\left.J=8.4,11.0 \mathrm{~Hz}\right)$ and $\mathrm{H}_{2}-10\left(\delta_{\mathrm{H}} 1.42,2.02\right)$ and their HMBC interactions with $\mathrm{C}-1\left(\delta_{\mathrm{C}} 80.9\right)$ and C-11 $\left(\delta_{\mathrm{C}} 40.6\right)$. Additional COSY relationships established the segments from $\mathrm{CH}-5$ to $\mathrm{CH}-7$ and $\mathrm{CH}-2$ to $\mathrm{CH}_{2}-3$. The connection of the segments across a quaternary carbon $\mathrm{C}-4\left(\delta_{\mathrm{C}} 72.1\right)$ was deduced by the $\mathrm{HMBC}$ correlations from $\mathrm{H}_{3}-15\left(\delta_{\mathrm{H}} 1.08 \mathrm{~s}\right)$ to $\mathrm{C}-3$ $\left(\delta_{\mathrm{C}} 44.9\right), \mathrm{C}-4\left(\delta_{\mathrm{C}} 72.1\right)$ and C-5 $\left(\delta_{\mathrm{C}} 143.2\right)$, while C-4 was co-positioned by a methyl and a hydroxy group. The linkage of $\mathrm{C}-2\left(\delta_{\mathrm{C}} 74.6\right)$ to $\mathrm{C}-1$ and $\mathrm{C}-8\left(\delta_{\mathrm{C}} 139.0\right)$ to $\mathrm{C}-9\left(\delta_{\mathrm{C}} 39.0\right)$ to form a cyclononene ring was ascribed to the $\mathrm{HMBC}$ relationships from $\mathrm{H}-9$ to $\mathrm{C}-7\left(\delta_{\mathrm{C}} 123.6\right), \mathrm{C}-8$ and $\mathrm{C}-2$, in addition to the correlations from $\mathrm{H}-7\left(\delta_{\mathrm{H}} 5.81\right.$, brs $)$ to $\mathrm{C}-9$ and $\mathrm{H}-2\left(\delta_{\mathrm{H}} 4.90\right.$, brd, $\left.J=3.6 \mathrm{~Hz}\right)$ to $\mathrm{C}-1$ and C-9. 
The location of a hydroxymethylene at C-8 was confirmed through the $\mathrm{HMBC}$ correlations from $\mathrm{H}_{2}-14$ $\left(\delta_{\mathrm{H}} 3.87,4.13, \mathrm{~d}, J=13.2 \mathrm{~Hz}\right)$ to $\mathrm{C}-7, \mathrm{C}-8$ and C-9, whereas two methyl groups resonated at $\delta_{\mathrm{H}} 1.03(\mathrm{~s})$ and $0.98(\mathrm{~s})$ were co-positioned at $\mathrm{C}-11$ on the basis of their protons correlated to $\mathrm{C}-1, \mathrm{C}-10\left(\delta_{\mathrm{C}} 33.5\right)$ and $\mathrm{C}-11$ in the HMBC spectrum. In addition, the HMBC correlation between $\mathrm{H}-2$ and the acetyl carbonyl carbon $\left(\delta_{\mathrm{C}} 170.8\right)$ clarified an acetoxy unit to be substituted at C-2. Thus, the gross structure was established as a caryophyllene-type sesquiterpene. The $J_{\mathrm{H}-5 / \mathrm{H}-6}(13.2 \mathrm{~Hz})$ value and the NOE interaction between $\mathrm{H}-7$ and $\mathrm{H}_{2}-14$ were in agreement with $5 Z$ and $7 E$ geometries. Additional NOE interactions from $\mathrm{H}_{3}-12$ to $\mathrm{H}-9$ and $\mathrm{H}-2$ indicated the same orientation of $\mathrm{H}-9$ and $\mathrm{H}-2$. The orientation of $\mathrm{OH}-1$ was supposed to be opposite to $\mathrm{H}-9$ on the basis of the NOE interaction between $\mathrm{H}-9$ and $\mathrm{H}-2$. The NOE correlations observed from $\mathrm{H}-15$ to $\mathrm{H}-3 \mathrm{~b}\left(\delta_{\mathrm{H}} 2.75\right)$ as well as from $\mathrm{H}-2$ to $\mathrm{H}-3 \mathrm{a}$ $\left(\delta_{\mathrm{H}} 1.36\right)$ indicated the opposite face of $\mathrm{H}_{3}-15$ toward $\mathrm{H}-2$. Thus, the structure of $\mathbf{1}$ was determined as a C-2 acetoxylated punctaporonin B [6]. The absolute configuration of $\mathbf{1}$ was determined as $1 S, 2 S, 4 S$, and $9 R$ by the results of the X-ray single-crystal diffraction using Flack parameters (Supplementary Information, Tables S1-S7 and Figure 2) [19].

Figure 2. X-ray crystal structures of punctaporonins H (1) and I (2).

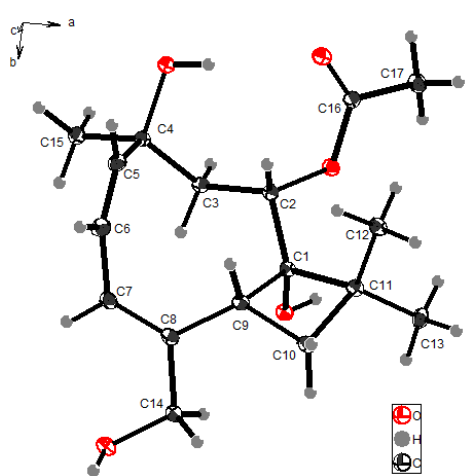

(1)

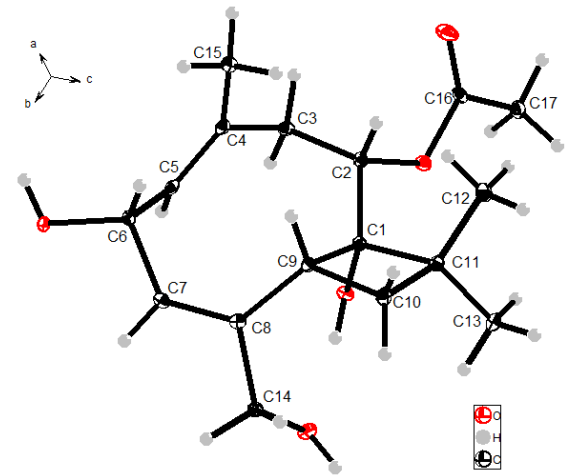

(2)

The NMR spectroscopic data of punctaporonin I (2) were closely related to those of $\mathbf{1}$, in fact both the compounds had the same molecular composition. However, C- $6\left(\delta_{C} 66.1\right)$ was found to be a hydroxymethine group based on the HSQC correlation, and was located in the allylic position of the two double bonds according to the COSY and HMBC correlations observed. The latter displayed long range contacts from $\mathrm{H}_{3}-15\left(\delta_{\mathrm{H}} 1.83\right.$, s) to $\mathrm{C}-3\left(\delta_{\mathrm{C}} 40.3\right), \mathrm{C}-4\left(\delta_{\mathrm{C}} 127.4\right)$ and $\mathrm{C}-5\left(\delta_{\mathrm{C}} 133.4\right)$, revealing one of the double bonds to be between C-4/C-5. The comparable NOE interactions of $\mathbf{1}$ and 2 in addition to the NOE correlations from $\mathrm{H}-6\left(\delta_{\mathrm{H}} 4.70\right)$ to $\mathrm{H}-9\left(\delta_{\mathrm{H}} 3.04\right)$ and $\mathrm{H}_{3}-15$ and between $\mathrm{H}-5$ $\left(\delta_{\mathrm{H}} 5.17\right)$ and $\mathrm{H}-3 \mathrm{~b}\left(\delta_{\mathrm{H}} 2.42, \mathrm{dd}, J=10.9,10.8 \mathrm{~Hz}\right)$ confirmed a syn orientation for H-6 and H-9 and $4 E$ geometry. Analysis of the X-ray single-crystal diffraction data (Supplementary Information, Tables S8-S14) revealed the absolute configurations of 2 to be $1 S, 2 S, 6 R$, and $9 R$. It is noteworthy that $\mathbf{2}$ is an unstable compound, which was partly converted to $4 Z$ isomer $\mathbf{2 a}$ with an ratio of 5:4 (2/2a) during the measurement of 2D NMR spectra in DMSO- $d_{6}$ (Figure 3). This assignment was supported by the NOE interactions between $\mathrm{H}_{3}-15 / \mathrm{H}-5$ and $\mathrm{H}-7 / \mathrm{H}_{2}-14$ for $\mathbf{2 a}$. 
Figure 3. Auto-conversion of $\mathbf{2}$ to $\mathbf{2 a}$ in DMSO.
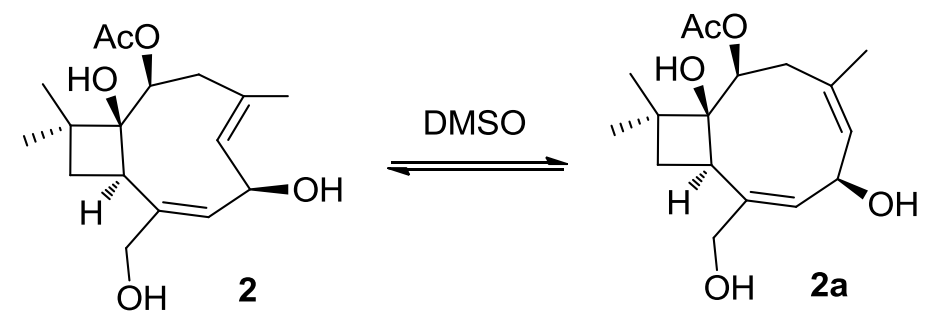

The molecular formula of punctaporonin $\mathbf{J}(3)$ was established as $\mathrm{C}_{23} \mathrm{H}_{35} \mathrm{NO}_{7}$ by the HRESIMS data $\left(m / z 438.2481[\mathrm{M}+\mathrm{H}]^{+}\right)$. The difference between $\mathbf{2}$ and $\mathbf{3}$ found in the NMR spectra was the presence of resonances of an exo-methylene at $\delta_{\mathrm{H}} 4.79,5.02 / \delta_{\mathrm{C}} 119.6$ and $\delta_{\mathrm{C}} 143.5$, an exchangeable proton at $\delta_{\mathrm{H}} 7.79$, and a side chain identified as (2E)-5-hydroxy-3-methylpent-2-enoyl group. The position of the exo-methylene group at C-4 was evident from its protons correlated to C-3 $\left(\delta_{\mathrm{C}} 35.1\right), \mathrm{C}-4\left(\delta_{\mathrm{C}} 143.5\right)$ and C-5 $\left(\delta_{\mathrm{C}} 62.5\right)$ in the HMBC spectrum. The side chain consisted of two olefinic carbons at $\delta_{\mathrm{C}} 120.6\left(\mathrm{C}-2^{\prime}\right)$ and $149.5\left(\mathrm{C}-3^{\prime}\right)$, a carbonyl carbon at $\delta_{\mathrm{C}} 166.4\left(\mathrm{C}-1^{\prime}\right)$, two methylenes and a methyl carbon. The COSY relationship between $\mathrm{H}_{2}-5^{\prime}\left(\delta_{\mathrm{H}} 2.21, \mathrm{t}\right)$ and $\mathrm{H}_{2}-6^{\prime}\left(\delta_{\mathrm{H}} 3.54, \mathrm{t}\right)$, in association with the HMBC interactions from $\mathrm{H}_{3}-4^{\prime}\left(\delta_{\mathrm{H}} 2.05\right.$, s ) to C-2', C-3' and C-5' $\left(\delta_{\mathrm{C}} 44.1\right)$ and from $\mathrm{H}-2^{\prime}$ $\left(\delta_{\mathrm{H}} 5.76, \mathrm{~s}\right)$ to $\mathrm{C}-1^{\prime}, \mathrm{C}-4^{\prime}\left(\delta_{\mathrm{C}} 18.2\right)$ and $\mathrm{C}-5^{\prime}$ and the NOE interaction between $\mathrm{H}-2^{\prime}$ and $\mathrm{H}_{2}-5^{\prime}$, established a (2E)-5-hydroxy-3-methylpent-2-enamide. The amide proton $\delta_{\mathrm{H}} 7.79$ (d) showing the COSY relationship with $\mathrm{H}-5\left(\delta_{\mathrm{H}} 4.10, \mathrm{t}\right)$ and the HMBC interactions with C-4, C-5 and C-6 confirmed the linkage of the amide moiety to C-5. The similar NOE interactions for the backbone of $\mathbf{3}$ and $\mathbf{2}$ in addition to the NOE correlations from H-9 $\left(\delta_{\mathrm{H}} 3.26\right)$ to H-5 and H-6 ( $\left.\delta_{\mathrm{H}} 4.36\right)$ assigned the same orientation of both H-5 and H-6 as H-9 (Figure 4).

Figure 4. Key HMBC, COSY and NOE correlations of 3 (ChemBioDraw Ultra 12.0, Cambridgesoft, Cambridge, MA, USA).
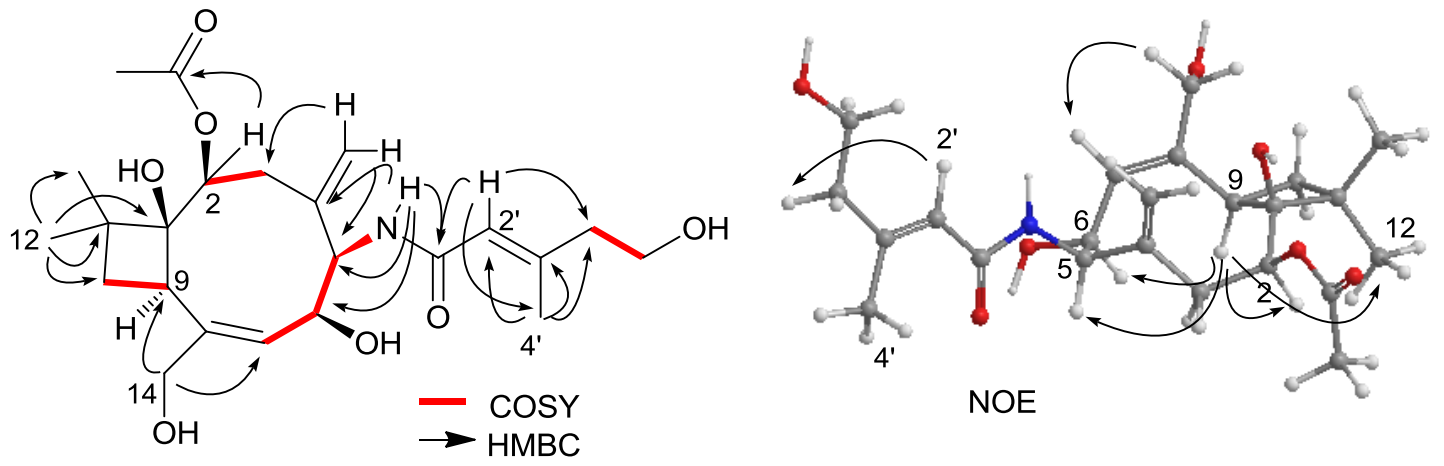

The structure of punctaporonin K (4) was determined as 2-deacetoxy analogue of $\mathbf{3}$ on the basis of the similar NMR data of both compounds with the exception of the absence of acetoxy group and the presence of a methylene at C-2 $\left(\delta_{\mathrm{C}} 32.9, \delta_{\mathrm{H}} 1.57,1.94, \mathrm{~m}\right)$.

The molecular formula of punctaporonin $\mathrm{L}(5)$ was established as $\mathrm{C}_{17} \mathrm{H}_{26} \mathrm{O}_{5}$ by its HRESIMS $\left(m / z 333.1677[\mathrm{M}+\mathrm{Na}]^{+}\right)$and NMR data. Comparison of the NMR data revealed the structure of $\mathbf{5}$ closely related to 6-hydroxypunctaporonin E [6]. The distinction was attributed to C-2 $\left(\delta_{\mathrm{C}} 71.4\right)$ of 5 being substituted by an acetoxy group $\left(\delta_{\mathrm{C}} 170.2,21.4 ; \delta_{\mathrm{H}} 1.94\right.$, s) instead of a hydroxy group, as 
evident from the HMBC interaction between $\mathrm{H}-2\left(\delta_{\mathrm{H}} 4.53\right.$, dd, $\left.J=4.8,11.2 \mathrm{~Hz}\right)$ and the acetyl carbonyl carbon $\left(\delta_{\mathrm{C}}\right.$ 170.2). The relative configurations of 5 were in accordance with those of 6-hydroxypunctaporonin $\mathrm{E}$ on the basis of the similar NOE interactions of both compounds. Since the absolute configurations of 6-hydroxypunctaporonin $\mathrm{E}$ were determined through $\mathrm{X}$-ray diffraction, the same sign and similar magnitude of the specific optical rotations for both compounds led us to assign $\mathbf{5}$ as possessing the same absolute configurations as the known analogue.

The NMR data for punctaporonin M (6) were closely similar to those of 5, except that $\mathrm{H}_{3}-15$ $\left(\delta_{\mathrm{H}} 0.85, \mathrm{~s}\right)$ of $\mathbf{6}$ showed an HMBC correlation with an oxygenated methine carbon $\left(\delta_{\mathrm{C}} 80.0, \mathrm{C}-5\right)$ instead of an olefinic carbon, and $\mathrm{H}_{2}-14\left(\delta_{\mathrm{H}} 3.46,3.53\right)$ exhibited the correlation with an olefinic carbon C-7 $\left(\delta_{\mathrm{C}} 132.2\right)$, indicating that C-5 of 6 was substituted by a hydroxy group and an olefinic bond resided at C-6/C-7. The similar ROE correlations of 5 and $\mathbf{6}$ (Figure 5), in association with the NOE interaction of H-2 ( $\left.\delta_{\mathrm{H}} 4.94, \mathrm{dd}, J=5.0,10.8 \mathrm{~Hz}\right)$ showing with $\mathrm{H}-5\left(\delta_{\mathrm{H}} 4.77, \mathrm{brs}\right), \mathrm{H}-9\left(\delta_{\mathrm{H}} 1.98, \mathrm{~m}\right)$, and $\mathrm{H}_{3}-12\left(\delta_{\mathrm{H}} 1.08, \mathrm{~s}\right)$, confirmed the same face of these protons. Additional NOE interaction between $\mathrm{H}_{2}-14$ and $\mathrm{H}_{3}-15$ was in agreement with the cis-fusion of the bicyclic ring (Figure 5).

Figure 5. Key NOE interactions of 5 and 6 (ChemBioDraw Ultra 12.0).
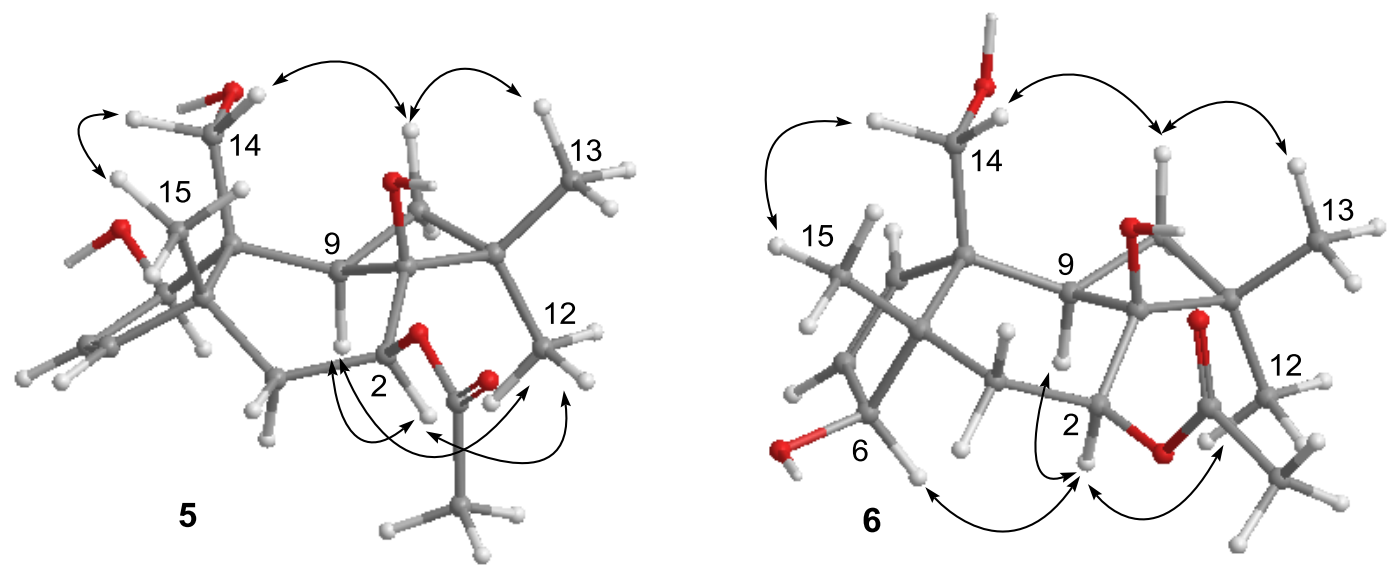

Two known analogues were identical to punctaporonin B (7) [11] and humulane (8) [10] on the basis of the comparison of their NMR and specific optical rotations with those reported in literature.

\subsection{Bioassay Results}

All compounds showed weak cytotoxic activity against a panel of tumor cell lines including human colon carcinoma HCT-8, human hepatoma Bel7402, human gastric carcinoma BGC823, human lung adenocarcinoma A549, and human ovarian carcinoma A2780 with $\mathrm{IC}_{50}$ values $>10 \mu \mathrm{M}$. These compounds also showed weak inhibitory effects against the bacterial strains of Escherichia coli, Staphylococcus aureus, Bacillus thuringensis, and Bacillus subtilis with the MIC values more than $125 \mu \mathrm{M}$.

Compounds 1-4 and 7-8 were tested for the lowering effects against oleic acid (OA)-elicited lipid accumulation in HepG2 liver cells. Compound 4 significantly reduced the OA-elicited lipid accumulation as measured by the oil-red O staining (Figure 6) [20], while the lowering effects of the intracellular total cholesterol (TC) and triglyceride (TG) quantification of 4 (Figure 7) were comparable to those induced by the positive control lovastatin and were in a dose dependent manner. 
Figure 6. Effects of compounds on oleic acid-elicited intracellular lipid accumulation. Cells were incubated with DMEM (Dulbecco's Modified Eagle Medium) + oleic acid (OA, $100 \mu \mathrm{M}$ ) for $12 \mathrm{~h}$, and then treated with $10 \mu \mathrm{M}$ of each compound with lovastatin as a positive control. The blank group was tested in DMEM alone, while DMEM + $100 \mu \mathrm{M}$ OA was used as a negative control. Neutral lipids were determined by spectrophotometry at $358 \mathrm{~nm}$ after oil-red O staining. Bars depict the means \pm SEM (standard error of mean) of at least three experiments. $* * * p<0.001$, OA vs. Blank; ${ }^{\dagger \dagger \dagger} p<0.001$, test group vs. OA group.

\section{Oil red O staining}

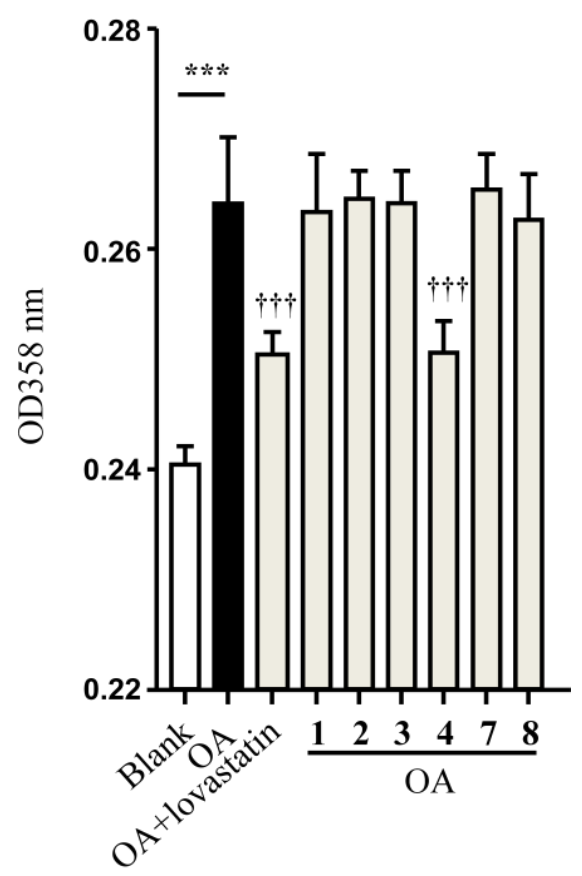

High cholesterol and/or triglyceride problems are known to increase risk for hypertension, diabetes mellitus, obesity and others that impact on coronary artery disease [21]. Lipid overaccumulation in liver is also a key cause for the development of insulin resistance [22,23]. High triglyceride levels are also a risk factor for acute pancreatitis. Decreasing lipid accumulation in liver is therefore beneficial for the prevention and treatment of diabetes. Modulating the dysregulation of lipid metabolism and decreasing the elevated levels of serum TC and TG are helpful for the treatment and prevention of cardiovascular disease [24]. Natural molecules such as resveratrol, cordycepin and chlorogenic acid have been investigated to be the capability of suppressing the lipogenesis and fat accumulation in liver tissues that induced obesity and diabetes [25,26]. However, regulation of lipid accumulation in cell level by caryophyllene-based derivatives has not been reported. In the present work, we reported caryophyllene-type analogue $\mathbf{4}$ as a new natural scaffold which could potently induce the reduction of $\mathrm{TC}$ and $\mathrm{TG}$ in liver cells for the first time. 
Figure 7. Inhibitory effects of $\mathbf{4}$ toward triglycerides and total cholesterol. Intracellular levels of triglycerides and total cholesterol were measured by kits according to the manufacturer's instructions. Bars depict the means \pm SEM of at least three experiments. *** $p<0.001$, OA vs. Blank; ${ }^{\dagger} p<0.01,{ }^{\dagger \dagger} p<0.001$, test group $v s$. OA group. OA: oleic acid.
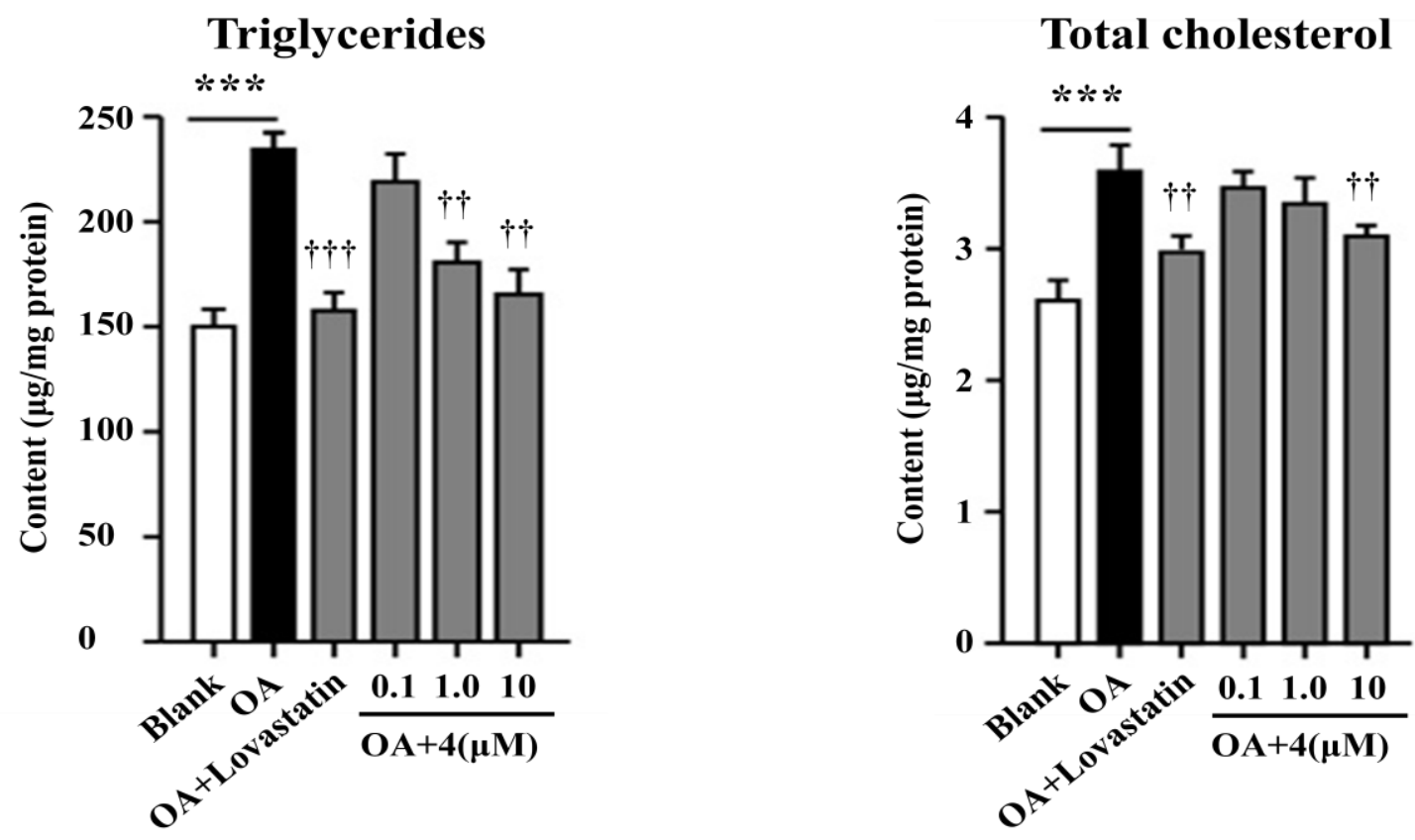

\section{Experimental Section}

\subsection{General Experimental Procedures}

Optical rotations were measured using an Autopol III automatic polarimeter (Rudolph Research Co., Hackettstown, NJ, USA). Melting points were measured on JGW-360A melting point apparatus (Xmchongda, Tech. Co., Xiamen, China). IR spectra were recorded on a Thermo Nicolet Nexus 470 FT-IR spectrometer (Thermo Fisher Scientific Inc., New York, NY, USA). NMR spectra were measured on a Bruker Avance-500 FT NMR spectrometer (Bruker Co., Bremen, Germany) (500 MHz) using TMS as the internal standard. HRESIMS spectra were obtained on a FT-MS-Bruker APEX IV (7.0 T) (Bruker Co., Bremen, Germany). X-ray diffraction was obtained on Bruker D8 Advance single crystal X-ray Diffractometer (Bruker Co., Karlsruhe, Germany). TLC detection was carried out using precoated silica gel $\mathrm{GF}_{254}$ plates (Yantai Chem. Ind., Yantai, China). Column chromatography was performed on Silica gel (200-300 mesh, Qingdao Marine Chemical Plant, Qingdao, China). Sephadex LH-20 $(18-110 \mu \mathrm{m})$ was obtained from Pharmacia Co. (Peapack, NJ, USA), and ODS $(50 \mu \mathrm{m})$ was provided by YMC Co. (Kyoto, Japan) High-performance liquid chromatography (HPLC) was performed on a Waters e2695 Separation Module (Waters, Milford, USA) coupled with a Waters 2998 photodiode array detector (Waters, Milford, CT, USA). A Kromasil $\mathrm{C}_{18}$ semipreparative HPLC column $(250 \times 10 \mathrm{~mm}, 5 \mu \mathrm{m})($ EKS Chemicals, Bohus, Sweden) was used for compound purification. All solvents were of analytical grade. 


\subsection{Fungal Material and Fermentation}

The fungal strain Hansfordia sinuosae was isolated from the sponge of Niphates sp. collected from Southern China Sea. The fungus was identified by morphological observation and analysis of the ITS region of the rDNA, whose sequence data have been deposited at GenBank with the accession number KF877718. The strain (WGCA-23-3A) was deposited at the State Key Laboratory of Natural and Biomimetic Drugs, Peking University, China. The fungal strain was cultured on slants of potato dextrose agar (PDA) at $25{ }^{\circ} \mathrm{C}$ for 10 days. Spore inoculum was prepared by suspension in distilled $\mathrm{H}_{2} \mathrm{O}$ to give a final spore/cell suspension of $1 \times 10^{6} / \mathrm{mL}$. A large scale fermentation was carried out in fifty $500 \mathrm{~mL}$ Fernbach flasks each containing $80 \mathrm{~g}$ of rice. Distilled $\mathrm{H}_{2} \mathrm{O}$ with sterilization brine $(100 \mathrm{~mL})$ was added to each flask, and the contents were soaked overnight before autoclaving at $15 \mathrm{lb} / \mathrm{in}^{2}$ (pound per square inch) for $30 \mathrm{~min}$. After cooling to room temperature, each flask was inoculated with $5.0 \mathrm{~mL}$ of the spore inoculum and incubated at $25^{\circ} \mathrm{C}$ for 35 days.

\subsection{Extraction and Isolation}

The fermented material was extracted with EtOAc $(3 \times 10 \mathrm{~L})$, and the organic layer was evaporated to dryness under vacuum to afford a crude extract $(99.0 \mathrm{~g})$. The extract was fractionated by a silica gel packed vacuum liquid chromatography (VLC) using petroleum ether-EtOAc gradient (5:1 to 1:1) as the eluent to afford six fractions (F1-F6). F4 (2.1 g) was subjected to an ODS column $(10 \mu \mathrm{m})$ eluting with a $\mathrm{MeOH}-\mathrm{H}_{2} \mathrm{O}$ gradient (from $30 \%$ to $100 \%$ ) to yield five subfractions (F4A-F4E). F4A (150 mg) was subjected to a Sephadex LH-20 column eluting with $\mathrm{MeOH}$ to yield 8 (3.2 $\mathrm{mg}$ ) and 7 (11.9 mg). F4E (300 mg) was separated on semipreparative HPLC (ODS) with 45\% Acetonitrile- $\mathrm{H}_{2} \mathrm{O}$ as a mobile phase to afford 1 (3.0 $\mathrm{mg}$, Rt $38.8 \mathrm{~min}$ ) and 2 (32.3 $\mathrm{mg}$, Rt $32.0 \mathrm{~min})$. F5 (557 mg) was subjected to Sephadex LH-20 column eluting with $\mathrm{MeOH}$ to give $3(13.0 \mathrm{mg})$ and $4(5.8 \mathrm{mg})$, while $\mathbf{5}(1.8 \mathrm{mg}$, Rt $45.4 \mathrm{~min}$ ) and 6 (3.0 $\mathrm{mg}$, Rt $29.4 \mathrm{~min}$ ) were separated by semipreparative HPLC with $36 \%$ Acetonitrile- $\mathrm{H}_{2} \mathrm{O}$ as a mobile phase.

Punctaporonin H (1). Colorless crystal. Mp. $152-154{ }^{\circ} \mathrm{C},[\alpha]_{\mathrm{D}}^{25}-83\left(c 0.3, \mathrm{CH}_{3} \mathrm{OH}\right) . \mathrm{UV}\left(\mathrm{CH}_{3} \mathrm{OH}\right)$ $\lambda_{\max }$ 208, $198 \mathrm{~nm}$; IR (KBr) $v_{\max }$ 3350, 2961, 2934, 2870, 1708, 1530, 1383, 1263, 1122, $1024 \mathrm{~cm}^{-1}$; ${ }^{1} \mathrm{H}$ and ${ }^{13} \mathrm{C}$ NMR data, see Table 1; HRESIMS $\mathrm{m} / z .333 .1675\left[\mathrm{M}+\mathrm{Na}^{+}\right.$(calcd for $\mathrm{C}_{17} \mathrm{H}_{26} \mathrm{NaO}_{5}, 333.1672$ ).

Punctaporonin I (2). Colorless crystal. Mp. 198-199 $\left.{ }^{\circ} \mathrm{C},[\alpha]_{\mathrm{D}}^{25}-139(c) 0.22, \mathrm{CH}_{3} \mathrm{OH}\right)$. UV $\left(\mathrm{CH}_{3} \mathrm{OH}\right) \lambda_{\max } 216,198 \mathrm{~nm}$; IR (KBr) $v_{\max } 3343,2932,2870,1714,1648,1620,1463,1373,1256$, $1122 \mathrm{~cm}^{-1}$; ${ }^{1} \mathrm{H}$ and ${ }^{13} \mathrm{C}$ NMR data, see Table 1; HRESIMS $\mathrm{m} / z 333.1669\left[\mathrm{M}+\mathrm{Na}^{+}\right.$(calcd for $\mathrm{C}_{17} \mathrm{H}_{26} \mathrm{NaO}_{5}, 333.1672$ ).

Punctaporonin J (3). Colorless oil, $[\alpha]_{\mathrm{D}}^{25}-37\left(c\right.$ 0.65, $\left.\mathrm{CH}_{3} \mathrm{OH}\right) . \mathrm{UV}\left(\mathrm{CH}_{3} \mathrm{OH}\right) \lambda_{\max } 221.1196 .5 \mathrm{~nm}$; IR (KBr) $v_{\max } 3326,2939,2873,1715,1664,1633,1537,1438,1373,1260,1047,1026 \mathrm{~cm}^{-1} ;{ }^{1} \mathrm{H}$ and ${ }^{13} \mathrm{C}$ NMR data, see Table 1; HRESIMS $m / z$ 438.2481 $[\mathrm{M}+\mathrm{H}]^{+}$(calcd for $\mathrm{C}_{23} \mathrm{H}_{36} \mathrm{NO}_{7}, 438.2486$ ).

Punctaporonin K (4). Colorless oil. $[\alpha]_{\mathrm{D}}^{25}-64\left(c 0.58, \mathrm{CH}_{3} \mathrm{OH}\right)$. UV $\left(\mathrm{CH}_{3} \mathrm{OH}\right) \lambda_{\max } 222,195 \mathrm{~nm}$; IR (KBr) $v_{\max } 3295$ (br), 2936, 2870, 1723, 1663, 1629, 1533, 1439, 1365, 1202, $1060 \mathrm{~cm}^{-1} ;{ }^{1} \mathrm{H}$ and ${ }^{13} \mathrm{C}$ NMR data, see Table 1; HRESIMS $m / z, 380.2429[\mathrm{M}+\mathrm{H}]^{+}$(calcd for $\mathrm{C}_{21} \mathrm{H}_{34} \mathrm{NO}_{5}, 380.2431$ ). 
Table 1. ${ }^{13} \mathrm{C}$ and ${ }^{1} \mathrm{H}$ NMR data for 1-6 in DMSO- $d_{6}$.

\begin{tabular}{|c|c|c|c|c|c|c|c|c|c|c|c|c|}
\hline \multirow{2}{*}{ No } & \multicolumn{2}{|r|}{1} & \multicolumn{2}{|r|}{2} & \multicolumn{2}{|r|}{3} & \multicolumn{2}{|r|}{4} & \multicolumn{2}{|r|}{5} & \multicolumn{2}{|r|}{6} \\
\hline & $\boldsymbol{\delta}_{\mathrm{C}}$ & $\delta_{\mathrm{H}}(J$ in $\mathbf{H z})$ & & $\delta_{\mathrm{H}}(J$ in $\mathbf{H z})$ & $\boldsymbol{\delta}_{\mathrm{C}}$ & $\delta_{H}(J$ in $\mathbf{H z})$ & $\boldsymbol{\delta}_{\mathrm{C}}$ & $\delta_{H}(J$ in $\mathbf{H z})$ & $\boldsymbol{\delta}_{\mathrm{C}}$ & $\delta_{\mathrm{H}}(J$ in $\mathbf{H z})$ & $\boldsymbol{\delta}_{\mathrm{C}}$ & $\delta_{\mathrm{H}}(J$ in $\mathbf{H z})$ \\
\hline 1 & 80.9 & & 81.2 & & 83.4 & & 82.7 & & 77.8 & & 77.5 & \\
\hline 2 & 74.6 & 4.90, brd (3.6) & 76.1 & $5.11, \mathrm{dd}(10.9,4.0)$ & 77.4 & 5.08, dd $(9.6,5.2)$ & 32.9 & $1.57, \mathrm{~m} ; 1.94, \mathrm{~m}$ & 71.4 & $4.53, \mathrm{dd}(11.2,4.8)$ & 70.8 & $4.94, \mathrm{dd}(10.8,5.0)$ \\
\hline 3 & 44.9 & $\begin{array}{l}1.36, \mathrm{~d}(15.8) \\
2.75, \mathrm{dd}(15.8,3.6)\end{array}$ & 40.3 & $\begin{array}{l}2.13, \mathrm{dd}(10.8,4.0) \\
2.42, \mathrm{dd}(10.9,10.8)\end{array}$ & 35.1 & $\begin{array}{l}2.19, \mathrm{dd}(11.0,9.6) \\
2.22, \mathrm{dd}(11.0,5.2)\end{array}$ & 28.7 & $\begin{array}{l}1.95, \text { brd (12.2) } \\
2.05, \mathrm{~m}\end{array}$ & 39.0 & $\begin{array}{l}1.66, \mathrm{dd}(12.3,4.8) \\
1.80, \mathrm{dd}(12.3,11.2)\end{array}$ & 36.5 & $\begin{array}{l}1.62 \text {, dd }(13.0,10.8) \\
1.81, \text { dd }(13.0,5.0)\end{array}$ \\
\hline 4 & 72.1 & & 127.4 & & 143.5 & & 148.3 & & 52.6 & & 54.4 & \\
\hline 5 & 143.2 & $5.75, \mathrm{~d}(13.2)$ & 133.4 & $5.17, \mathrm{~d}(9.8)$ & 62.5 & $4.10, \mathrm{t}(8.0)$ & 62.3 & $4.24, \mathrm{t}(8.5)$ & 145.6 & $5.71, \mathrm{~d}(5.6)$ & 80.0 & 4.77 , brs \\
\hline 6 & 124.3 & 5.63 , brd (13.2) & 66.1 & $4.70, \mathrm{dd},(9.8,4.2)$ & 69.5 & $4.36, \mathrm{dd}(9.0,8.0)$ & 69.6 & $4.43, \mathrm{dd}(8.5,9.2)$ & 130.1 & $5.61, \mathrm{dd}(5.6,2.6)$ & 136.1 & 5.52, brd $(6.0)$ \\
\hline 7 & 123.6 & 5.81 , brs & 141.8 & $5.83, \mathrm{~s}$ & 133.3 & $5.38, \mathrm{~d}(9.0)$ & 131.5 & $5.36, \mathrm{~d}(9.2)$ & 80.3 & $3.94, \mathrm{~d}(2.6)$ & 132.2 & $5.48, \mathrm{~d}(6.0)$ \\
\hline 8 & 139.0 & & 136.1 & & 136.1 & & 137.2 & & 49.4 & & 53.5 & \\
\hline 9 & 39.0 & 3.26 , dd $(11.0,8.4)$ & 40.6 & $3.04, \mathrm{dd}(10.2,7.9)$ & 40.8 & $3.26, \mathrm{t}(10.0)$ & 43.9 & 3.16 , dd $(9.0,8.7)$ & 42.7 & $2.00, \mathrm{~m}$ & 45.3 & $1.98, \mathrm{~m}$ \\
\hline 10 & 33.5 & $\begin{array}{l}1.42, \mathrm{dd}(9.1,8.4) \\
2.02, \mathrm{dd}(11.0,9.1)\end{array}$ & 33.3 & $\begin{array}{l}1.57, \mathrm{dd}(12.0,10.2) \\
1.92, \mathrm{dd}(12.0,7.9)\end{array}$ & 33.8 & $\begin{array}{l}1.43, \mathrm{t}(10.0) \\
2.04, \mathrm{t}(10.0)\end{array}$ & 33.7 & $\begin{array}{l}1.46, \mathrm{dd}(9.0,8.7) \\
2.02, \mathrm{t}(9.0)\end{array}$ & 35.4 & $\begin{array}{l}1.50, \mathrm{~m} \\
2.00, \mathrm{~m}\end{array}$ & 35.4 & $\begin{array}{l}1.39, \mathrm{dd}(5.0,4.5) \\
2.00, \mathrm{~m}\end{array}$ \\
\hline 11 & 40.6 & & 41.6 & & 41.0 & & 40.9 & & 41.6 & & 42.5 & \\
\hline 12 & 24.5 & $1.03, \mathrm{~s}$ & 24.5 & $0.94, \mathrm{~s}$ & 24.7 & $1.08, \mathrm{~s}$ & 24.3 & $1.07, \mathrm{~s}$ & 23.6 & $1.02, \mathrm{~s}$ & 23.7 & $1.08, \mathrm{~s}$ \\
\hline 13 & 24.1 & $0.98, \mathrm{~s}$ & 25.5 & $1.02, \mathrm{~s}$ & 24.0 & $0.98, \mathrm{~s}$ & 22.5 & $0.86, \mathrm{~s}$ & 24.3 & $0.98, \mathrm{~s}$ & 24.3 & $0.97, \mathrm{~s}$ \\
\hline 14 & 63.4 & $\begin{array}{l}3.87, \mathrm{~d}(13.2) \\
4.13, \mathrm{~d}(13.2)\end{array}$ & 65.4 & $\begin{array}{l}3.78, \mathrm{~d}(11.2) \\
4.11, \mathrm{~d}(11.2)\end{array}$ & 64.3 & $\begin{array}{l}3.76, \mathrm{~d}(11.0) \\
3.94, \mathrm{~d}(11.0)\end{array}$ & 64.3 & $\begin{array}{l}3.74, \mathrm{~d}(12.4) \\
3.90, \mathrm{~d}(12.4)\end{array}$ & 60.3 & $\begin{array}{l}3.50, \mathrm{~d}(11.0) \\
3.93, \mathrm{~d}(11.0)\end{array}$ & 61.9 & $\begin{array}{l}3.46, \mathrm{~d}(11.0) \\
3.53, \mathrm{~d}(11.0)\end{array}$ \\
\hline 15 & 31.9 & $1.08, \mathrm{~s}$ & 17.5 & $1.83, \mathrm{~s}$ & 119.6 & $4.79, \mathrm{~s} ; 5.02, \mathrm{~s}$ & 117.9 & $4.66, \mathrm{~s} ; 4.86, \mathrm{~s}$ & 27.3 & $1.15, \mathrm{~s}$ & 17.8 & $0.85, \mathrm{~s}$ \\
\hline $\begin{array}{l}1^{\prime} \\
2^{\prime}\end{array}$ & & & & & $\begin{array}{l}166.4 \\
120.6\end{array}$ & $576 \mathrm{~s}$ & $\begin{array}{l}166.4 \\
1206\end{array}$ & $576 \mathrm{~s}$ & & & & \\
\hline $\begin{array}{l}2^{\prime} \\
3^{\prime}\end{array}$ & & & & & $\begin{array}{l}120.6 \\
149.5\end{array}$ & $5.76, \mathrm{~s}$ & $\begin{array}{l}120.6 \\
149.4\end{array}$ & $5.76, \mathrm{~s}$ & & & & \\
\hline $4^{\prime}$ & & & & & 18.2 & $2.05, \mathrm{~s}$ & 18.2 & $2.07, \mathrm{~s}$ & & & & \\
\hline $5^{\prime}$ & & & & & 44.1 & $2.21, \mathrm{t}(6.2)$ & 44.1 & $2.20, \mathrm{t}(6.2)$ & & & & \\
\hline $6^{\prime}$ & & & & & 59.6 & $3.54, \mathrm{t}(6.5)$ & 59.5 & $3.54, \mathrm{t}(6.5)$ & & & & \\
\hline Ac & 170.8 & & 170.1 & & 169.8 & & & & 170.2 & & 170.1 & \\
\hline $\mathrm{NH}$ & 21.6 & $1.99, \mathrm{~s}$ & 21.7 & $1.96, \mathrm{~s}$ & 21.5 & $\begin{array}{l}1.97, \mathrm{~s} \\
7.79, \mathrm{~d}(8.0)\end{array}$ & & 7.92, d (8.5) & 21.4 & $1.94, \mathrm{~s}$ & 21.4 & $1.97, \mathrm{~s}$ \\
\hline
\end{tabular}


Punctaporonin L (5). White powder. $[\alpha]_{\mathrm{D}}^{25}-48\left(c 0.10, \mathrm{CH}_{3} \mathrm{OH}\right)$; UV $\left(\mathrm{CH}_{3} \mathrm{OH}\right) \lambda_{\max } 199 \mathrm{~nm}$; IR $(\mathrm{KBr}) v_{\max } 3336,2952,2933,2870,1729,1682,1529,1454,1350,1251,1028 \mathrm{~cm}^{-1} ;{ }^{1} \mathrm{H}$ and ${ }^{13} \mathrm{C} \mathrm{NMR}$ data, see Table 1; HRESIMS $m / z 333.1677[\mathrm{M}+\mathrm{Na}]^{+}$(calcd for $\mathrm{C}_{17} \mathrm{H}_{26} \mathrm{O}_{5} \mathrm{Na}, 333.1672$ ).

Punctaporonin M (6). White powder. $[\alpha]_{\mathrm{D}}^{25}+49\left(c\right.$ 0.12, $\left.\mathrm{CH}_{3} \mathrm{OH}\right) . \mathrm{UV}\left(\mathrm{CH}_{3} \mathrm{OH}\right) \lambda_{\max } 199 \mathrm{~nm}$; IR (KBr) $v_{\max } 3265,2957,2933,2865,1718$ (br), 1463, 1377, 1249, $1017 \mathrm{~cm}^{-1}$; ${ }^{1} \mathrm{H}$ and ${ }^{13} \mathrm{C}$ NMR data, see Table 1; HRESIMS m/z 333.1677 [M+ Na] $]^{+}$(calcd for $\mathrm{C}_{17} \mathrm{H}_{26} \mathrm{O}_{5} \mathrm{Na}, 333.1672$ ).

\subsection{X-Ray Single Crystallographic Analyses}

Punctaporonin $\mathrm{H}$ (1) and punctaporonin I (2) were crystallized from $\mathrm{MeOH}-\mathrm{CH}_{2} \mathrm{Cl}_{2}$ (1:1) at room temperature. The X-ray crystallographic data of both compounds (see Supplementary information) were obtained on a Bruker SMART CCD detector employing graphite monochromated $\mathrm{Cu}-\mathrm{K} \alpha$ radiation (operated in the $\varphi-\omega$ scan mode). The structures were solved by direct method using SHELXS-97 [27] and refined with full-matrix least-squares calculations on F2 using SHELXL-97 [27].

Crystal data of punctaporonin $\mathrm{H}: \mathrm{C}_{17} \mathrm{H}_{26} \mathrm{O}_{5}, M=310.38$, monoclinic, $a=9.3925(11) \AA$, $b=9.3490(9) \AA, c=9.8735(9) \AA, \beta=107.503(12)^{\circ}, U=826.86(15) \AA^{3}, T=98.5$, space group $\mathrm{P} 2{ }_{1}$ (No. 4$), \mathrm{Z}=2, \mu(\mathrm{Cu} \mathrm{K} \alpha)=0.741,5653$ reflections measured, 2970 unique $\left(R_{\text {int }}=0.0315\right)$ which were used in all calculations. The final $w R\left(F_{2}\right)$ was 0.1288 (all data).

Crystal data of punctaporonin I: $\mathrm{C}_{17} \mathrm{H}_{26} \mathrm{O}_{5}, M=310.38$, orthorhombic, $a=11.2742(10) \AA$, $b=11.7414(11) \AA, c=12.020(2) \AA, U=1591.2(4) \AA^{3}, T=99.7$, space group $\mathrm{P} 2{ }_{1} 2_{1} 2_{1}$ (No. 19), $\mathrm{Z}=4$, $\mu(\mathrm{Cu} \mathrm{K \alpha})=0.771,5650$ reflections measured, 2964 unique $\left(R_{\mathrm{int}}=0.0301\right)$ which were used in all calculations. The final $w R\left(F_{2}\right)$ was 0.0970 (all data).

The crystallographic data for the structures of punctaporonins H (1) and I (2) have been deposited in the Cambridge Crystallographic Data Centre (deposition numbers: CCDC 974950 for 1 and CCDC 974951 for 2). Copies of the data can be obtained free of charge, on application to the director, CCDC [28], 12 Union Road, Cambridge CB21EZ, UK (Fax: +44-(0)1223-336033, or E-Mail: deposit@ccdc.cam.ac.uk).

\subsection{Cell-Based Lipid Accumulation Assay}

HepG2 cells were maintained in DMEM medium supplemented with $10 \%$ fetal bovine serum and penicillin/streptomycin $(100 \mu \mathrm{g} / \mathrm{mL})$. The cells with $70 \%-80 \%$ confluence were incubated in DMEM + oleic acid $(100 \mu \mathrm{M})$ for $12 \mathrm{~h}$, then were treated with the compounds (each, $10 \mu \mathrm{M})$ and a positive control lovastatin in DMEM/100 $\mu \mathrm{M}$ oleic acid with DMEM/100 $\mu \mathrm{M}$ oleic acid as a blank for additional $6 \mathrm{~h}$. Subsequently, the cells were subjected to oil-red O staining or TC and TG determination as described previously [20]. Each experiment ( $n=8$ for oil-red O staining or $n=3$ for TC and TG determination) was repeated in triplication.

\subsection{Cytotoxic and Antibacterial Assays}

The cytotoxic assay was performed by a standard MTT method. Antimicrobial activities were measured against the bacterial strains of Escherichia coli, Staphylococcus aureus, Bacillus thuringensis, 
and Bacillus subtilis, by the broth microdilution method. The bacteria were grown for $16 \mathrm{~h}$ on a rotary shaker at $37{ }^{\circ} \mathrm{C}$. Cultures were diluted with sterile medium to achieve an optical absorbance of 0.4-0.06 at $600 \mathrm{~nm}$, then further diluted 10-fold before transferring into 96-well microtiter plates. Three replicates of each compound were tested in $125 \mu \mathrm{g} / \mathrm{mL}$. The optical absorbance at $600 \mathrm{~nm}$ was measured after cultivation for $18 \mathrm{~h}$. The lowest concentrations that completely inhibited visible growth of the tested strains were recorded from three independent experiments.

\section{Conclusions}

In biogenetic consideration, the tricyclic 5 was depicted to be derived from 1 through a transannular cyclization [29] by C-4/C-8 cycloaddition, whereas $\mathbf{6}$ was suggested to be derived from $\mathbf{5}$ via olefinic rearrangement. The 5-hydroxy-3-methyl-2-pentenamide unit in $\mathbf{3}$ and $\mathbf{4}$ was found from nature for the first time, while this unit was biogenetically considered to be generated through the mevalonate pathway. However, the mechanism for introducing nitrogen to form an amide instead of an ester is unknown. The significant effects of compound $\mathbf{4}$ to reduce the triglycerides and total cholesterol in the intracellular levels suggested it could be a potent lead compound for the development of a drug candidate for lowering lipids.

\section{Acknowledgments}

This work was supported by grants from COMRA (DY125-15-T-01) and SOA (201031912 3366025-4), NSFC (No. 30930109), and National Hi-Tech 863-Projects (2011AA090701, 2013AA092902, 2013AA093003).

\section{Author Contributions}

Performed the isolation and structural elucidation: $\mathrm{Z}$. Wu. Selected and cultured the microorganism: D. Liu. Tested and evaluated the bioactivities of compounds: P. Guo. Conceived and designed the experiments and wrote the paper: P. Proksch and W. Lin.

\section{Conflicts of Interest}

The authors declare no conflict of interest.

\section{References}

1. Collado, I.G.; Hanson, J.R.; Macías-Sánchez, A.J. Recent advances in the chemistry of caryophyllene. Nat. Prod. Rep. 1998, 15, 187-204.

2. Ghalib, R.M.; Hashim, R.; Sulaiman, O.; Mehdi, S.H.; Valkonen, A.; Rissanen, K.; Trifunovi, S.R.; Ahamed, M.B.K.; Majid, A.M.S.A. A novel caryophyllene type sesquiterpene lactone from Asparagus falcatus (Linn.); Structure elucidation and anti-angiogenic activity on HUVECs. Eur. J. Med. Chem. 2012, 47, 601-607.

3. Orav, A.; Stulova, I.; Kailas, T.; Muurisepp, M. Effect of storage on the essential oil composition of Piper nigrum L. fruits of different ripening states. J. Agric. Food Chem. 2004, 52, 2582-2586. 
4. Mockute, D.; Bernotiene, G.; Judzentiene, A. The essential oil of Origanum vulgare L. ssp. vulgare growing wild in Vilnius district (Lithuania). Phytochemistry 2001, 57, 65-69.

5. Li, Y.; Cui, C.; Liu, X.; Che, Y. Cytosporinols A-C, new caryophyllene sesquiterpenoids from Cytospora sp. Nat. Prod. Bioprospect. 2012, 2, 70-75.

6. Deyrup, S.T.; Swenson, D.C.; Gloer, J.B.; Wicklow, D.T. Caryophyllene sesquiterpenoids from a fungicolous isolate of Pestalotiopsis disseminate. J. Nat. Prod. 2006, 69, 608-611.

7. Yang, S.; Chan, T.M.; Terracciano, J.; Boehm, E.; Patel, R.; Chen, G.; Loebenberg, D.; Patel, M.; Gullo, V.; Pramanik, B.; et al. Caryophyllenes from a fungal culture of Chrysosporium pilosum. J. Nat. Prod. 2009, 72, 484-487.

8. Wichlacz, M.; Ayer, W.A.; Trifonov, L.S.; Chakravarty, P.; Khasa, D. A caryophyllene-related sesquiterpene and two 6,7-seco-caryophyllenes from liquid cultures of Hebeloma longicaudum. J. Nat. Prod. 1999, 62, 484-486.

9. Pulici, M.; Sugawara, F.; Koshino, H.; Uzawa, J.; Yoshida, S. Pestalotiopsins A and B: New caryophyllenes from an endophytic fungus of Taxus brevifolia. J. Org. Chem. 1996, 61, 2122-2124.

10. Pulici, M.; Sugawara, F.; Koshino, H.; Okada, G.; Esumi, Y.; Uzawa, J.; Yoshida, S. Metabolites of Pestalotiopsis spp., endophytic fungi of Taxus brevifolia. Phytochemistry 1997, 46, 313-319.

11. Anderson, J.R.; Edwards, R.L.; Poyser, J.P.; Whalley, A.J.S. Metabolites of the higher fungi 23. the punctaporonins novel bi-cyclic, tri-cyclic, and tetra-cyclic sesquiterpenes related to caryophyliene, from the fungus Poronia punctata (Linnaeus, Fries) Fries. J. Chem. Soc. Perkin Trans. 1 1988, 4 , 823-831.

12. Anderson, J.R.; Edwards, R.L.; Freer, A.A.; Mabelis, R.P.; Poyser, J.P.; Spencer, H.; Whalley, A.J.S. Punctatins B and C (antibiotics M95154 and M95155): Further sesquiterpene alcohols from the fungus Poronia punctata. J. Chem. Soc. Chem. Commun. 1984, 14, 917-919.

13. Ahmed, A.F.; Su, J.H.; Shiue, R.T.; Pan, X.J.; Dai, C.F.; Kuo, Y.H.; Sheu, J.H. New $\beta$-caryophyllene-derived terpenoids from the soft coral Sinularia nanolobata. J. Nat. Prod. 2004, 67, 592-597.

14. Chen, W.; Li, Y.; Guo, Y. Terpenoids of Sinularia soft corals: Chemistry and bioactivity. Acta Pharm. Sin. B 2012, 2, 227-237.

15. Wang, G.H.; Ahmed, A.F.; Sheu, J.H.; Duh, C.Y.; Shen, Y.C.; Wang, L.T. Suberosols A-D, four new sesquiterpenes with $\beta$-caryophyllene skeletons from a Taiwanese gorgonian coral Subergorgia suberosa. J. Nat. Prod. 2002, 65, 887-891.

16. Smetanina, O.F.; Kuznetsova, T.A.; Gerasimenko, A.V.; Kalinovsky, A.I.; Pivkin, M.V.; Dmitrenok, P.C.; Elyakov, G.B. Metabolites of the marine fungus Humicola fuscoatra KMM 4629. Russ. Chem. Bull. 2004, 53, 2643-2646.

17. Collado, I.G.; Aleu, J.; Macias-Sanchez, A.J.; Hernandez-Galan, R. Inhibition of Botrytzas cznerea by new sesquiterpenoid compounds obtained from the rearrangement of isocaryophyllene. J. Nat. Prod. 1994, 57, 738-746.

18. Poyser, J.P.; Edwards, R.L.; Hursthouse, M.B.; Walker, N.P.C.; Sheldrick, G.M.; Whalley, A.J.S. Punctaporonins A, D, E, and F (antibiotics M95464, M167906, M171950, and M189122), isomeric allylic alcohols from the fungus Poronia punctata: X-ray crystal structures of D and of E acetonide. J. Antibiot. 1986, 39, 167-169. 
19. Flack, H.D. On enantiomorph-polatity estimation. Acta Cryst. 1983, 39, 876-881.

20. Zhang, X.; Wu, C.; Wu, H.; Sheng, L.; Su, Y.; Zhang, X.; Luan, H.; Sun, G.; Sun, X.; Tian, Y.; et al. Anti-hyperlipidemic effects and potential mechanisms of action of the caffeoylquinic acid-rich Pandanus tectorius fruit extract in hamsters fed a high fat-diet. PLoS One 2013, 8, e61922.

21. Ghuge, G.D.; Zine, R.; Mogrekar, M. Lipid profile of patients with ischaemic heart disease from rural area of Marthawada region, India. Int. J. Biomed. Adv. Res. 2012, 3, 767-769.

22. Kumashiro, N.; Erion, D.M.; Zhang, D.; Kahn, M.; Beddow, S.A.; Chu, X.; Still, C.D.; Gerhard, G.S.; Han, X.; Dziura, J. Cellular mechanism of insulin resistance in nonalcoholic fatty liver disease. Proc. Natl. Acad. Sci. USA 2011, 108, 16381-16385.

23. D’Adamo, E.; Cali, A.M.; Weiss, R.; Santoro, N.; Pierpont, B.; Northrup, V.; Caprio, S. Central role of fatty liver in the pathogenesis of insulin resistance in obese adolescents. Diabetes Care 2010, 33, 1817-1822.

24. Wan, C.W.; Wong, C.N.; Pin, W.K.; Wong, M.H.; Kwok, C.Y.; Chan, R.Y.; Yu, P.H.; Chan, S.W. Chlorogenic acid exhibits cholesterol lowering and fatty liver attenuating properties by up-regulating the gene expression of PPAR-alpha in hypercholesterolemic rats induced with a high-cholesterol diet. Phytother. Res. 2013, 27, 545-551.

25. Poulsen, M.M.; Larsen, J.O.; Hamilton-Dutoit, S.; Clasen, B.F.; Jessen, N.; Paulsen, S.K.; Kjaer, T.N.; Richelsen, B.; Pedersen, S.B. Resveratrol up-regulates hepatic uncoupling protein 2 and prevents development of nonalcoholic fatty liver disease in rats fed a high-fat diet. Nutr. Res. 2012, 32, 701-708.

26. Guo, P.; Kai, Q.; Gao, J.; Lian, Z.Q.; Wu, C.M.; Wu, C.A.; Zhu, H.B. Cordycepin prevents hyperlipidemia in hamsters fed a high-fat diet via activation of AMP-activated protein kinase. J. Pharmacol. Sci. 2010, 113, 395-403.

27. Sheldrick, G.M. A short history of SHELX. Acta Cryst. 2008, A64, 112-122.

28. The Cambridge Crystallographic Data Centre (CCDC). Available online: http://www.ccdc.cam.ac.uk (accessed on 20 June 2014).

29. Kobayashi, M.; Nakano, E. Stereochemical course of the transannular cyclization, in chloroform, of epoxycembranoids derived from the geometrical isomers of (14S)-14-hydroxy-1,3,7, 11-cembratetraen. J. Org. Chem. 1990, 55, 1947-1951.

(C) 2014 by the authors; licensee MDPI, Basel, Switzerland. This article is an open access article distributed under the terms and conditions of the Creative Commons Attribution license (http://creativecommons.org/licenses/by/3.0/). 